\title{
IMPLEMENTASI KONSEP BELAJAR KOGNITIVISME DALAM MATA PELAJARAN IPA SEKOLAH DASAR
}

\author{
Mita Evina \\ Institut Agama Islam Syarifuddin Lumajang, Indonesia \\ Email: mitaayubgs45@gmail.com
}

\begin{abstract}
Abstrak
Rendahnya kemampuan pedagodik guru mempengaruhi dalam melakukan suatu kegiatan pembelajaran yang bersifat praktikum di kelas V SDN Barat 02 Padang, Lumajang dan pembelajaran yang bersifat ceramah dan penugasan yang dilakukan guru pada saat proses penyampaian pembelajaran berlangsung di SDN BARAT 02 Padang, Lumajang.

Penelitian ini menggunakan metode deskriptif kualitatif, teknik pengumpulan data mengunakan observasi, wawancara dan study doccument.

Penelitian ini menunjukan tentang konsep belajar kognitivisme yang merupakan proses pembelajaran melibatkan kegiatan mental yang ada dalam diri siswa dan implementasi konsep belajar kognitivisme melalui praktikum dalam mata pelajaran IPA di kelas V SDN Barat 02 Padang, Lumajang, guru melakukan persiapan dari berbagai hal, dari materi yang akan disampaikan hingga bahan yang digunakan praktik dan hal dipentingkan saat proses pembelajaran oleh guru dengan sebaik mungkin. Kata kunci: Konsep Belajar Kognitivisme, Pelajaran IPA
\end{abstract}

\section{Pendahuluan}

Pendidikan merupakan suatu hal yang harus dilakukan di dalam Negeri ataupun di luar Negeri, karena melalui pendidikan seseorang dapat mengetahui semua hal yang belum mereka ketahui. Menurut UU No. 20 tahun 2003 tentang Sisdiknas, Pendidikan adalah sebuah usaha yang dilakukan secara sadar dan terencana untuk mewujudkan suasana belajar dan proses pembelajaran agar peserta didik secara aktif mengembangkan potensi dirinya untuk memiliki kekuatan spiritual keagamaaan, membangun kepribadian, pengendalian diri, kecerdasan, akhlak mulia, serta keterampilan yang diperlukan dirinya, Masyarakat, 
Bangsa, dan Negara. ${ }^{1}$ Dalam pengertian yang agak luas, pendidikan dapat diartikan sebagai sebuah proses dengan metode-metode tertentu sehingga orang memperoleh pengetahuan, pemahaman, dan cara tingkah laku yang sesuai dengan kebutuhan. ${ }^{2}$ Pernyataan tersebut bahwasaannya dalam konsep pendidikan terdapat suatu kata belajar yang mana pendidikan merupakan suatu proses yang terdapat beberapa metode-metode dan strategi, sehingga metode dan strategi tersebut merupakan suatu kata yang ada saat proses pembelajaran berlangsung.

Belajar merupakan suatu proses perubahan yaitu perubahan tingkah laku sebagai hasil interaksi dengan lingkungannya dalam memenuhi kebutuhan hidupnya, ${ }^{3}$ Perubahan-perubahan tersebut akan nyata dengan adanya sikap tingkah laku dan sifat kognitif seorang siswa sebagai pendukung. Dalam keseluruhan proses pendidikan di Sekolah, kegiatan belajar merupakan kegiatan yang paling pokok, ini berarti keberhasilan suatu perubahan tingkah laku tergantung kepada bagimana proses belajar yang dialami oleh siswa sebagai peserta didik.

Siswa memperoleh suatu pengetahuan dengan belajar tidak harus di Sekolah tetapi juga diluar Sekolah, dalam pergaulan seorang siswa dapat belajar secara terus menerus, karena itu sebagai pendukung. Sekolah harus bekerja sama dengan orang tua dan masyarakat agar sifat potensi kognitif anak dapat berjalan sesuai dengan pengetahuan yang ada di Sekolah,4 pernyataan tersebut merupakan hal yang menunjukkan bahwasannya pendidikan merupakan hal yang harus terwujud di dalam sekolah atau di luar sekolah.

Suatu proses pembelajaran seorang anak ketika di dalam Sekolah saat proses pembelajaran berlangsung seorang guru harus mengarahkan

\footnotetext{
${ }^{1}$ Evi Rine Hartuti, Undang-Undang Republik Indonesia Nomor 20 Tahun 2003 Tentang Sistem Pendidikan Nasional, (Jogjakarta: Laksana, 2012), 11.

2 Muhibbin syah, Psikologi pendidikan dengan pendekatan baru, (Bandung: Remaja

Rosdakarya, 2005), 10.

${ }^{3}$ Slameto, Belajar dan faktor-faktor yang mempengaruhi, (jakarta: Rineka cipta, 2005), 2.

${ }^{4}$ Mohammad jauhar, implementasi PAIKEM,( Jakarta,prestasi pustakaraya, 2011) 34
} 
pemikiran anak dengan pembelajaran yang mengunakan hal yang kongkrit, dikarenakan proses pembelajaran yang dimaksut dalam penelitian ini adalah pada saat anak usia 7-12 tahun yang mana pembelajaran pada usia tersebut anak banyak membutuhkan pemahaman yang bersifat kongkrit bukan hal yang bersifat abstrak, akan tetapi jika saat proses pembelajaran berlangsung seorang guru tidak banyak mengunakan pembelajaran yang bersifat kogkrit maka tidak dapat dipungkiri jika kognitif anak tidak akan berkembang sesuai dengan porsi daya kognitif anak.

Pembelajaran yang bersifat abstrak memang harus di uji cobakan kepada anak akan tetapi jika memang anak sudah dapat menalar dengan baik dengan syarat seorang Guru tidak harus terlalu mengekspor pembelajaran yang bersifat abstrak tersebut dengan secara gamblang sehingga anak tidak dapat memahami, akan tetapi seorang guru harus benar-benar mendampingi kegiatan anak tersebut dengan baik. Pembelajaran yang dilakukan seorang guru pada saat proses pembelajaran berlangsung seharusnya tidak hanya menyampaikan materi pembelajaran dengan proses atau metode yang membosankan anak seperti halnya ceramah saja, seorang guru harus memberikan penyampaian pembelajaran dengan berbagai kreasi atau berbagai metode dan strategi, banyaknya metode yang harus digunakan seorang guru pada saat proses pembelajaran berlangsung akan memberikan pemahaman yang baik kepada siswa, metode ceramah memang dibutuhkan saat proses pembelajaran berlangsung akan tetapi harus dipadukan dengan metode pembelajaran yang lain juga saat pembelajaran, dengan banyaknya metode-metode yang digunakan seorang guru, maka guru akan lebih mudah menyampaikan suatu materi pembelajaran kepada anak dan anak akan memahami pembelajaran dengan baik begitu juga saat pembelajaran juga anak tidak akan merasa bosan. 
Seorang guru juga harus memperbanyak pengetahuan tentang beberapa konsep pendidikan seperti konsep belajar kognitivisme, konsep belajar behaviorisme, konsep belajar konstruktivisme dan konsep belajar humanisme, yang mana dalam setiap konsep belajar tersebut mempunyai sifat dan ciri khas yang berbeda-beda antara konsep belajar yang satu dengan yang lainnya. Seperti halnya konsep pada teori kognitivisme, yang mana konsep belajar kognitivisme ini menekankan pada tingkah laku atau mental anak untuk melakukan suatu hal percobaan atau yang bersifat praktikum saat berada di sekolah, hal tersebut tidak hanya berupa stimulus dan respon belaka, akan tetapi dalam kegiatan tersebut mental anak akan terarah oleh dorongan kognitif seorang anak. Apalagi kebanyakan seorang anak diusia SD/MI masih menyukai pembelajaran yang bersifat kongkrit atau yang bersifat nyata, dan saat pembelajaran anak tidak hanya sekedar stimulus dan respon yang mereka dapat, melainkan dari kegiatan stimulus dan respons inilah seorang anak mengunakan tindakan dalam mengenal suatu pembelajaran.

Begitu dengan konsep pada teori kognitivisme ini, konsep dalam teori kognitivisme ini adalah semacam suatu kegiatan yang dilakukan secara berulang-ulang dan dengan cara pembiasaan, penelitian ini mengunakan pengimplementasian pada teori kognitivisme dalam proses pembelajaran khususnya pada mata pelajaran IPA. Ilmu Pengetahuan Alam atau yang sering disebut IPA merupakan salah satu mata pelajaran penting di sekolah dasar, IPA sendiri mempelajari segala sesuatu yang ada di alam, baik itu mahluk hidup maupun benda-benda mati, seperti hewan, tumbuhan, manusia, matahari, planet-planet, benda-benda angkasa, tanah, air, udara, dan lain sebagainnya. IPA juga mempelajari sifat-sifat benda seperti gaya, gerak dan energi. ${ }^{5}$ Mata pelajaran IPA merupakan salah satu mata pelajaran yang banyak melakukan suatu

${ }^{5}$ Suwarno dkk, materi lengkap IPA untuk sekolah dasar,(Jakarta selatan, PT suka buku, 2010) 5 
kegiatan yang bersifat praktikum dan sifat tersebut dapat dilakukan dengan kebiasaan anak sehingga pembelajaran yang didapat di sekolah dapat terealisasikan dengan lingkungan, yang menyangkut kejadian yang ada di alam sekitar manusia.

Dari hasil pengamatan, SDN Barat 02 dalam pelaksanaan pembelajaran di kelas penggunaan konsep kognitivisme dalam proses praktikum saat pembelajaran masih sangat rendah dan guru cenderung menggunakan pembelajaran yang bersifat ceramah pada setiap pembelajaran yang dilakukannya. Sehingga berpengaruh pada hasil belajar siswa. Hal ini mungkin disebabkan kurangnya penguasaan guru terhadap konsep pembelajaran yang ada, padahal penguasaan terhadap konsep pembelajaran sangat diperlukan untuk meningkatkan kemampuan profesional guru.

Didalam suatu tindakan mental seorang anak pada situasi belajar, dengan keterlibatan seorang anak atau siswa secara langsung dalam situasi belajar tersebut akan menghasilkan pemahaman yang dapat mudah diingat dan tidak mudah dilupakan, situasi seperti ini dapat membantu individu tersebut memecahkan masalah. Dengan kata lain, yang paling penting dalam proses belajar individu adalah dimengertinya apa yang dipelajari oleh individu tersebut. Suatu kegiatan eksperimen atau praktikum dapat dilakukan dalam proses pembelajaran yaitu dengan cara suatu kegiatan pembelajaran yang dilakukan secara langsung, siswa melakukan dengan bersama teman-temannya saat proses pembelajaran, sehingga siswa akan mudah memahami suatu pembelajaran dalam jangka panjang. Konsep belajar kognitivisme ini merupakan salah satu aliran yang mempunyai pengaruh terhadap praktik pembelajaran yang dilaksanakan di sekolah, salah satunya pada pelajaran IPA.

Didalam lingkungan sekolah pada tempat penelitian awal ini dilakukan yaitu di SDN Barat 02 yang bertempat tinggal di Desa Barat Kecamatan Padang Kabupaten Lumajang, saat peneliti melaksanakan 
pengamatan disetiap kelas hampir saat semua mata pelajaran guru dalam menjelaskan materi mengunakan metode ceramah dan jarang sekali terdapat tanya jawab. Dan selama penelitian berlangsung tidak pernah dilakukannya suatu kegiatan praktikum disekolah kecuali pada mata pelajaran olah raga atau yang disebut penjaskes. Kejadian ini juga dilakukan saat mata pelajaran itu memang menbutuhkan praktik, akan tetapi guru hanya menjelaskan dengan disertai contoh, dan itu bukanlah hal yang mudah dipahami oleh seorang siswa yang memang pelajaran tersebut benar-benar butuh dengan praktikum.

\section{Pembahasan}

\section{Konsep belajar kognitivisme}

Belajar merupakan suatu proses perubahan yaitu perubahan tingkah laku sebagai hasil dari interaksi dengan lingkungannya dalam memehuni kebutuhan hidupnya. ${ }^{6}$ Belajar memiliki pengertian memperoleh pengetahuan atau menguasai pengetahuan melalui pengalaman, mengingat, menguasai pengalaman, dan mendapatkan informasi atau menemukan, dengan demikian belajar memiliki arti dasar adanya aktivitas atau kegiatan dan penguasaan tentang sesuatu.

Adapaun prinsip dalam pembelajaran yang harus diperhatikan seorang guru antara lain: Apapun yang dipelajari siswa, dialah yang harus belajar, bukan orang lain. Untuk itu siswalah yang harus bertindak aktif. Setiap siswa belajar sesuai dengan tingkat kemampuannya. Siswa akan dapat belajar dengan baik bila mendapat penguatan langsung pada setiap langkah yang dilakukan selama proses pembelajaran. Penguasaan yang sempurna daris etiap langkah yang dilakukan siswa akan membuat proses belajar lebih berarti. Motivasi belajar siswa akan lebih meningkat apabila siswa diberi tangung jawab dan kepercayaan penuh atas belajarnya.

\footnotetext{
${ }^{6}$ Slameto.belajar dan faktor-faktor yang mempengaruhi. 2
} 
Belajar memiliki beberapa konsep yang mana konsep tersebut memiliki bermacam - macam perbedaan meliputi: Konsep belajar behaviorisme. Belajar benurut behaviorisme merupakan belajar yang hanya mengunakan stimulus dan respon saja, stimulus dalam proses pembelajaran menurut konsep behavirisme ini sangat memengaruhi terhadap menghasilkannya respon. Yang mana teori ini dikemukakan oleh beberapa ilmuan seperti Ivan Pavlov, Edward Lee Throndike, Burrhus Frederic Skinner, Edwin R Gutri, Clark Hull. ${ }^{7}$ Konsep belajar kognitivisme. Belajar dalam konsep kognitivisme ini bukan hanya memandang suatu pembelajaran sebagai stimulus dan respon saja seperti yang dikemukakan konsep belajar behaviorisme, akan tetapi pada konsep kognitivisme ini kegiatan atau proses pembelajaran melibatkan kegiatan mental yang ada dalam diri individu yang sedang belajar, dengan kata lain adalah siswa atau peserta didik. Konsep belajar ini dikemukakan beberapa ilmuan seperti Wolfgang Kohler, Kurf Koffka, dan Jean Peaget. 8 Konsep belajar konstruktivisme. Belajar menurut konsep konstruktivisme ini adalah bahwa guru tidak begitu saja memberikan pengetahuan kepada siswa, tetapi siswalah yang harus aktif membangun pengetahuan dalam pikiran mereka sendiri. Pendekatan dalam proses belajar ini didasarkan pada perpaduan antara beberapa penelitian dalam psikologi kogmitif dan psikologi sosial, konstruktivisme ini memahami hakikat belajar sebagai kegiatan manusia membangun atau menciptakan pengetahuan dengan cara mencoba memberi makna pada pengetahuan sesuai pengalamannya. Konsep belajar humanism. Belajar menurut konsep humanisme memandang bahwa belajar bukan sekedar pengembangan kualitas kognitif saja, melainkan juga sebuah proses yang terjadi dalam diri individu yang melibatkan seluruh bagian atau domain yang ada. Belajar merupakan suatu kegiatan yang berproses dan merupakan unsur yang

7 Baharuddin. Teori belajar dan pembelajaran. 83

${ }^{8}$ Baharuddin.teori belajar dan pembelajaran. 125 
sangat fundamental dalam setiap penyelenggaraan jenis dan jenjang pendidikan. ${ }^{9}$ Dalam perspektif psikologi kognitif, belajar pada asasnya adalah peristiwa mental, bukan peristiwa behavioral (yang bersifat jasmaniah) meskipun hal - hal yang bersifat behavioral tampak lebih nyata dalam setiap peristiwa belajar siswa. Secara lahiriyah, seorang anak yang sedang belajar membaca dan menulis, misalnya, tentu mengunakan perangkat jasmaniah (dalam hal ini mulut dan tangan) untuk mengucapkan kata-kata dan menulis. Akan tetapi perilaku mengucapkan kata-kata dan menulis yang dilakukan siswa tersebut bukan semata-mata respons atau stimulus yang ada, melainkan yang lebih penting karena dorongan mental yang diatur oleh otaknya.

Teori belajar ini mengacu pada wacana psikologi kognitif, yang didasarkan pada kegiatan kognitif siswa dalam belajar. Para ahli teori ini berupaya menganalisis secara ilmiah proses mental dan struktur ingatan atau cognition dalam proses belajar. Cognition diartikan sebagai aktivitas mengetahui, memperoleh pengetahuan, mengorganisasikan, dan menggunakannya. Belajar kognitif berlangsung berdasarkan schemata atau struktur mental individu yang mengorganisasikan hasil pengamatannya. Struktur mental individu tersebut berkembang sesuai dengan tingkatan perkembangan kognitif seseorang. Semakin tinggi tingkat perkembangan kognitif seseorang, semakin tinggi pula kemampaun dan keterampilan dalam memproses berbagai informasi atau pengetahuan yang diterimanya dari lingkungan.

Pertumbuhan intelektual anak mengandung tiga aspek yaitu struktur, content, dan function. Anak yang sedang mengalami perkembangan, struktur, dan konten intelektualnya berubah/berkembang. Fungsi dan adaptasi akan tersusun sehingga melahirkan suatu rangkaian perkembangan, masing-masing mempunyai

\footnotetext{
${ }^{9}$ Muhibin syah, psikologi pendidikan dengan pendekatan baru, [ Pt remaja rosdakarya, Bandung, 2005] 89
} 
struktur psikologi khusus yang menentukan kecakapan pikiran anak. Maka, Piaget mengartikan intelegensi adalah sejumlah struktur psikologis yang ada pada tingkat perkembangan khusus.

Teori kognitif ini lebih menegangkan bagaimana proses untuk mengoptimalkan aspek rasional yang dimiliki oleh orang lain dalam kehidupan sehari hari kita lebih sering mendengar kata kognitif dari aspek tenaga pendidik misalnya seorang guru diharuskan memiliki kompetensi bidang kognitif artinya seorang guru harus memiliki kemampuan intelektual seperti penguasaan materi pelajaran, pengetahuan mengenaai cara mengajar. Setiap suatu teori pembelajaran pastilah terdapat kelebihan dan kekuragan yang antara lain adalah: Kelebihannya yaitu sebagian besar dalam kurikulum di Indonesia lebih menekankan pada teori kognitif yang mengutamakan pada pengembangan pengengetahuan yang dimiliki pada setiap individu. Pada metode pembelajaran kognitif pendidik hanya perlu memberikan dasar-dasar dari materi yang diajarkan untuk pengembangan dan kelanjutannya diserahkan kepada peserta didik, dan pendidik hanya perlu memantau dan menjelaskan alur pengembangan materi yang diberikan. Dengan menerapkan teori kognitif ini maka pendidik dapat memaksimalkan ingatan yang dimiliki peserta didik. Pembelajaran ini sama artinya dengan kreasi atau pembuatan satu hal baru dari suatu hal yang suadah ada.

Kekurangan Pada dasarnya teori kognitif ini lebih menekankan pada kemampuan ingatan peserta didik, dan kemampuan ingatan masing-masing peserta didik, sehingga kelemahan yang terjadi disini adalah menganggap semua peserta didik itu mempunyai kemampuan daya ingat yang sama dan tidak berbeda-beda. Adakalanya juga dalam metode ini tidak memperhatikan cara peserta didik dalam mengeksprorasi atau mengembangkan pengetahuan dengan cara-cara peserta didik dalam mencarinya, karena pada dasarnya pesreta didik memiliki cara yang berbeda-beda, apabila dalam pengajaran hanya mengunakan metode kognitif, maka pastikan peserta didik tidak 
mengerti sepenuhnya materi yang diberikan. Adapun pada saat pembelajaran dilaksanakan peneliti melakukan pelaksanaan penelitian pada mata pelajaran IPA tentang materi materi gaya dan pesawat sederhana. Adapun setelah dipaparkannya berbagai penjelasan tentang konsep kognitivisme maka dalam pembahasan yang selanjutnya akan dipaparkan data temuan peneliti tentang Implementasi Konsep Belajar Kognitivisme Dalam Mata Pelajaran Ipa Di Kelas V Sdn Barat 02 Kecamatan PadangKabupaten Lumajang Tahun Pelajaran 2017-2018 Sesuai fokus penelitian di awal, maka data yang telah diperoleh dari lapangan disajikan sebagai berikut: yaitu konsep belajar kognitivisme dalam mata pelajaran IPA dikelas V SDN Barat 02 Kecamatan Padang Kabupaten Lumajang pada tahun pelajaran 2017-2018.

Seorang guru konsep belajar kognitivisme merupakan suatu pembelajaraan yang bersifat pembiasaan yang dilakukan seorang anak dengan mengunakan pemikiran atau akal seorang anak. Seorang guru saat proses pembelajaran tidaklah harus memberikan suatu materi pembelajaran secara singkat atau secara panjang lebar akan tetapi seorang anak tidak dapat memahami penjelasan dari seorang guru. Seorang guru seharusya juga dapat memahami sifat karakter seorang anak didiknya sehingga nanti seorang guru dalam menjelaskan dapat diresapi dan dapat dipahami oleh anak didiknya, didalam pembelajaran seorang guru tidak harus dengan membekali dengan materi secara terus menerus, akan tetapi seorang guru harus memberikan suatu konsep pembelajaran dengan kehidupan yang ada disekeliling anak atau di luar kelas.

Konsep belajar kognitivisme sendiri dalam proses pembelajaran merupakan suatu kegiatan yang bersifat praktikum melalui pembiasaan yang ada di sekolah atau di lingkungan rumahnya. Seperti yang tertera dalam teori yang ada dibab sebelumya bahwasannya suatu kegiatan pembelajaran yang didasarkan pada kognitif dan pembelajaran yang melibatkan fisik, maka siswa akan lebih mengingat lebih lama dari hal 
pembelajaran yang hanya mengandalkan ceramah, hal tersebut senada dengan apa yang diungkapkan oleh pak Dimyati selaku guru kelas V di SDN Barat 02 bahwasannya. "Suatu ketika pembelajaran yang dilakukan atau diberikan guru pada murit hanya dengan proses ceramah tidak disertai dengan contoh secara nyata, maka anak akan dengan mudah melupakan materi yang diberikan oleh guru, bahkan selesai penjelasan dari guru akan hilang saat mengikuti kegiatan yang selanjutnya". ${ }^{10}$

Dari di atas peneliti dapat menjelaskan bahwasaanya dari teori kognitif ini dalam proses pembelajaran akan berguna untuk membantu seorang guru dalam menjelaskan materi pelajaran. Dalam hal pelajaran IPA (ilmu pengetahuan alam), seorang guru yang mungkin sulit untuk menjelaskan materi yang tidak dimengerti oleh siswa seperti materi gaya gravitasi, padahal materi sudah dijelaskan, maka seorang guru lebih baik memberikan contoh yang ada dilingkungan kelas. Maka tanpa sadar siswa akan memahami apa yang dilihat dari kejadikan yang dicontohkan oleh guru. Dan siswa akan menganalisa dari penjelasan yang diberikan guru dengan apa yang dicontohkan oleh guru, siswa akan mudah memahami dan mudah menginggat.

Dari observasi yang peneliti lihat bahwasaannya kegiatan yang dilakukan guru kelas pada saat proses pembelajaran, guru menerangkan materi secara detail, akan tetapi guru tidak memberikan praktikum pada saat materi tersebut membutuhkan praktik, guru hanya memberi contoh dengan bayangan atau hal yang tidak abstrak, hal tersebut membuat siswa tidak begitu memahami penjelasan guru yang secara detail tersebut.11 Akan tetapi saat Wawancara yang dilakukan peneliti saat proses observasi pada guru kelas tentang konsep belajar kognitivisme, apakah pernah melakukan kegiatan yang pembelajaran yang bersifat kognitovisme? Dan apakah siswa pernah melakukan kegiatan

${ }^{10}$ Dimyati, wawancara, Barat. 15 april 2018

${ }^{11}$ Observasi. Guru kelas. Barat, 15 April 2018 
pembelajaran yang bersifat kognitivisme melalui kegiatan praktikum?. Pak Dimyati selaku wali kelas V menjelaskan “ bahwasannya disekolah SDN Barat 02 ini pernah melakukan kegiatan yang bersifat kognitivisme saat proses pembelajaran yang berupa memberi contoh pada materi yang terdapat contoh, akan tetapi itu hanya dilakukan oleh guru saja. dan siswa tidak pernah melakukan kegiatan pembelajaran yang bersifat kognitivisme melalui kegiatan praktikum dengan guru kelas ditahun ini, pada tahun lalu pernah ada kegiatan praktikum tentang fotosintesis, dan hanya sekali itu dilakukannya kegiatan praktikum disekolah"12

Dari data tersebut peneliti dapat beranggapan bahwasaanya sekolah SDN Barat 02 ini siswanya masih belum terbiasa melakukan praktikum, Saat melakukan kegiatan observasi peneliti juga melakukan wawancara dengan salah satu siswa bernama yogik apakah saat proses pembelajaran guru menjelaskan materi ceramah saja? Dan bagaimana situasi saat proses pembelajaran berlangsung?. Adapun yang dikatakaan oleh yogik adalah: "saat pembelajaran dikelas teman-temannya sering kali bergurau sendiri saat pak Dimyati menjelaskan. Pak Dim saat menjelaskan materi ceramah dan menulis jarang sekali memberikan contoh". ${ }^{13}$ Dari hasil wawancara siswa dapat mendukung apa yang dilaksanakan guru kelas bahwasaanya suatu pembelajaran yang jarang sekali guru memberikan suatu contoh. Peneliti masih mengajukan pertanyaan pada seorang siswa dengan pertanyaan yang dijawab oleh yogik, yang mana siswa menjawab dengan tidak jauh beda yang dijelaskan oleh yogik dan peneliti menambah pertanyaan, Apakah kalian tidak bosan saat pembelajaran selalu didalam kelas? Dan bagaimana jika suatu saat pembelajaran pada mata pelajaran tertentu melakukan suatu kegiatan praktikum? Adapun yang dikatakan oleh Ima siswi kelas $\mathrm{V}$ adalah "pelajaran dikelas terus menerus ya terkadang membosankan, akan tetapi bagaimana lagi ini sudah ketentuan

12 Dimyati,wawancara. Barat. 15 april 2018

${ }^{13}$ Yogik,wawancara. Barat. 16 april 2018 
dari sekolah. Pembelajaran diluar kelas hanya pada mata pelajaran penjaskes, selain itu tidak pernah melakukan kegiatan pembelajaran diluar kelas. Dan apabila memang sekolah mau mengadakan suatu praktikum, kami senang sekali, agar kami dalam pembelajaran dapat mengingat dan terus diingat oleh siswa yang memang sering pelupa. ${ }^{14}$

Pendapat dari siswa tersebut dapat menjadi tambahan pengajuan kepada guru kelas bahwasaannya siswa juga mengingikan adanya sebuah praktikum di sekolah tidak memandang berada didalam kelas atau diluar kelas. Menurut pengamatan yang peneliti lakukan dari kelas yang satu dengan kelas yang lainnya, seorang guru kebanyakan melakukan kegiatan pembelajaran bersifat ceramah saja, tidak jauh beda dari apa yang diungkapkan oleh pak Dimyati atau yang siswa bilang bahwasaanya tidak pernah melakukan praktek, sehingga peneliti berdiskusi dengan guru kelas V untuk melakukan kegiatan praktik pada saat pelajaran berlangsung yaitu pada mata pelajaran IPA dengan materi pelajaran gaya dan pesawat sederhana. Mungkin saat melakukan praktek yang pertama kali temen-temen masih gak terlalu faham dan masih bingung dengan apa yang dilakukan.

Dalam proses penelitian ini guru kelas melakukan suatu kegiatan yang berkonsep kognitivisme pada mata pelajaran IPA, dari kegiatan yang guru jelaskan sendiri dikelas dengan memberi contoh, lalu guru mengajak siswa - siswinya untuk melakukan kegiatan praktikum seperti yang diinginkan oleh siswa-siswinya dikelas V SDN Barat 02. Hal ini pertama kali yang dilakukan oleh guru kelas begitu juga dengan siswasiswinya, dan kegiatan ini cukup lama dilakukan oleh guru kelas pada mata pelajaran IPA saja selama kurang lebih empat pertemuan atau satu bulan. Sehingga guru kelas dapat melakukan kegiatan praktikum ini dengan mata pelajaran yang lain seperti pada mata pelajaran matematika yang anak diajak membuat bangun ruang seperti kubus, balok dll.

14 Ima, wawancara, 20 april 2018 
Setelah peneliti perhatikan proses kegiatan praktikum berlangsung siswa memperhatikan dengan seksama apa yang dicontohkan oleh guru kelas dan siswa dapat mengikuti kegiatan tersebut dengan baik walau pada awal kegiatan masih bingung dan canggung dengan apa yang dilakukan, dan siswa dapat menyerap materi dengan baik dan dapat dibuktikan dengan adanya ulangan yang diberikan oleh guru pada saat kegiatan ulangan harian kelas. peneliti dapat menyimpulkan bahwasannya kegiatan yang dilakukan disekolah dengan proses pembelajaran didalam kelas atau diluar kelas cukup efektif bagi siswa dikarenakan saat proses pembelajaran guru mengunakan pembelajaran dengan konsep kognitivisme dalam bentuk praktikum, sehingga siswa banyak yang begitu memahami pembelajaran dengan mengunakana metode ceramah dengan dibarengi konsep kognitivisme, dan juga jika seorang guru belajar berbagai konsep pembelajaran atau berbagai metode-metode maka pembelajaran didalam kelas menjadi lebih efektif. ${ }^{15}$

\section{Mata Pelajaran IPA}

Pada saat pelaksanaan konsep belajar kognitivisme seorang guru harus menyiapkan pembelajaran yang akan dilakukan oleh siswa, siswa dalam proses pembelajaran diajak untuk mengabungkan antara pembelajaran yang didapat didalam kelas dengan pembelajaran yang diluar kelas dengan praktikum yang dihubungkan dengan pembiasan seorang siswa pada kehidupan sehari-hari. Suatu proses pemahaman seorang anak juga harus dilakukan dengan berbagai kegiatan praktikum, bukan dengan mata pelajaran IPA saja akan tetapi dari berbagai mata pelajaran. Pelaksanaan pembelajaraan dengan konsep kognitivisne ini juga harus direncanakn seorang guru agar pembelajaran dapat dilakukan dengan sebaik-baiknya.

Dari hasil observasi yang peneliti peroleh bahwasannya dalam menerapkan atau pelaksanaan konsep belajar kognitivisme pada mata

${ }^{15}$ Observasi, guru kelas V. 21 mei -2018 
pelajaran IPA di kelas V SDN Barat 02 kecamatan padang kabupaten Lumajang dilakukan dengan beberapa tahap ${ }^{16}$, yakni: Tahab pertama ( pesiapan guru) yaitu dari hasil observasi peneliti, bahwasannya di SDN Barat 02 tepatnya di kelas $\mathrm{V}$, sebelum mengajar guru sudah mempersiapkan materi yang akan disampaikan kepada siswanya dan bahan yang akan digunakan untuk melaksanakan praktikum. Selanjutnya guru terlebih dahulu menjelaskan isi materi pokok pelajaran yang akan dipelajari. Penjelasan diperlukan karena penjelasan yang kurang yang berada dalam buku, guru harus menuturkan secara lisan. ${ }^{17}$ Menjelaskan pada dasarnya adalah menuturkan secara lisan mengenai sesuatu bahan pelajaran, maka keterampilan secara sistematis dan terencana sehingga memudahkan siswa untuk memahami bahan pembelajaran. Sebelum siswa melakukan kegiatan pembelajaran praktikum, terlebih dahulu saya mempersiapkan bahan yang digunakan dalam praktikum dan menjelaskan materi yang akan dipelajari oleh siswa dan juga langkahlangkahnya yang saya tuangkan dalam RPP. Tujuannya agar proses pembelajaran berjalan sesuai yang sudah direncanakan serta siswa dapat memahami materi yang diberikan dengan tepat."18

Berdasarkan hasil wawancara dan observasi diatas, dapat peneliti analisis bahwasanya sebelum proses pembelajaran berlangsung terlebih dahulu guru mempersiapkan materi dan bahan untuk melaksanakan praktikum serta langkah-langkahnya mengikuti pelajaran IPA dengan menggunakan konsep belajar kognitivisme dalam bentuk praktikum yang dituangkan dalam RPP. Waktu yang digunakan dalam pelajaran IPA adalah 2 jam. Sedangkan dalam pembagian waktunya adalah 30 menit, guru menjelaskan materi dan siswa memahami materi dari penjelasan guru beserta contoh yang diperlukan dalam materi IPA, pembelajaran dengan menggunakan konsep kognitivisme dalam bentuk praktikum

\footnotetext{
16 Observasi, Guru kelas V. 21 - Mei- 2018

17 Observasi, Lumajang, 19 Mei 2018.

18 observasi, Lumajang, 19 Maret 2018.
} 
dilakukan selama 1 Jam, 30 menit berikutnya digunakan siswa dan guru untuk evaluasi hasil praktikum bersama teman dan guru.

Pada tahab kedua ( pelaksanaan) yaitu dari hasil observasi peneliti, dalam tahap pelaksanaan ini, guru mempersiapkan dan membawa bahan praktikum pada saat pertemuan pertama melakukan kegiatan tersebut. Karena kegiatan ini baru siswa lakukan sehingga guru harus menyiapkan terlebih dahulu dan pada pertemuan selanjutnya kegiatan dilakukan dengan bahan siswa yang menyediakan dari rumah. Hal ini berupaya agar siswa dapat turut andil mengikuti pelajaran dengan seksama dengan diadakannya bahan yang siswa bawa dari rumah, dan siswa akan selalu bertanya-tanya, apa yang akan mereka lakukan pada saat proses pembelajaran berlangsung. Di SDN Barat 02 khususnya di kelas $\mathrm{V}$, dalam pelaksanaan pembelajaran IPA dengan menggunakan konsep belajar kognitivisme dengan beberapa langkah-langkah, yakni:Guru memberi kesempatan kepada siswa untuk membaca materi sejenak. Guru memberikan penjelasan tentang materi yang akan dipelajari serta memberi contoh dari materi yang telah dijelaskan. Guru meminta kepada siswa untuk membentuk kelompok. Siswa mendiskusikan apa yang telah dijelaskan oleh guru untuk melakukan praktikum seperti apa yang dicontohkan guru. Siswa menjelaskan dan mempraktikan didepan teman yang lainnya. Guru memberikan ulasan terhadap hasil praktik siswa, selanjutnya bersama-sama siswa dan guru memberi kesimpulan.Guru memberikan motivasi kepada peserta didik. ${ }^{19}$

Berdasarkan hasil observasi diatas, dapat peneliti analisis bahwasannya di SDN Barat 02 dalam proses pembelajaran IPA dengan menggunakan konsep kognitivisme dilakukan dengan Praktik pada pertemuan pertama guru memberi contoh terlebih dahulu lalu siswa dengan kelompok akan menirukan dan mempraktikan apa yang telah dipahami dari penjelasan guru. Dan praktik pada pertemuan selanjutnya

19 Observasi, Guru Kelas V, Lumajang, 19 Mei 2018. 
guru kelas melakukan diskusi dan siswa melaksanakan praktik dan menjelaskan didepan kelas atau didepan teman kelompok yang lain begitu seterusnya pada kegiatan praktikum dengan dibarengi berbagai macam metode dan strategi pada kegiatan pembelajaran berlangsung. Dalam sebuah penelitian yang ditelah dilakukan peneliti maka hasil dari proses penelitian yang sesuai dengan fokus penelitian antara lain yang pertama yaitu konsep belajar kognitivisme dalam mata pelajaran IPA dikelas V SDN Barat 02 Kecamatan Padang Kabupaten Lumajang pada tahun pelajaran 2017-2018. Dari hasil observasi peneliti melihat bahwasanya dalam proses pelaksanaan pembelajaran IPA dengan mengunakan konsep belajar kognitivisme melalui praktikum. Guru kelas pada awalnya memang kesulitan dalam melaksanakan persiapan praktikum akan tetapi guru kelas tidak mundur dengan begitu saja untuk merubah suatu kegiatan didalam kelas dengan kebiasaan yang dahulu, pada awal pertemuan melakukan praktikum guru menjelaskan seperti biasa lalu mencontohkan, kemudian siswa diajak untuk diskusi dengan teman-temannya dengan dibagi kelompok, lalu mereka akan meragakan apa yang disampaikan guru dalam materi tersebut. Hal ini oleh guru disesuaikan dengan apa yang telah direncanakan dan dituangkan dalam bentuk RPP yang telah dibuatnya.

Pada kegiatan praktikum yang kedua dan yang seterusnya, guru hanya menjelaskan tanpa melakukan contoh. Lalu guru membentuk kelompok kembali. Sesuai dengan yang telah ditentukan oleh guru, kemudian satu persatu kelompok mempaktikkan apa yang telah dijelaskan oleh guru, meskipun ada sebagian siswa yang bingung akan tetapi masih dapat mengikuti kegiatan praktikum dengan baik dengan dibantun teman sekelompoknya. Seorang siswa yang lain dalam hal proses pembelajaran dengan praktikum ini membantu teman yang tidak memahami dan diberi arahan oleh guru bahwasannya hal ini menuntun siswa untuk bersolidaritas dengan teman yang lainnya agar tidak 
tertinggal dalam proses pembelajaran ini. Pada saat terdapat kejadian tersebut dapat peneliti pahami bahwasaanya guru kelas membentuk suatu kegiatan dengan diskusi dapat memudahkan siswa yang malu bertanya pada guru kelas saat proses pembelajaran, dan teman sebayanya dan teman sekelompoknya yang menjadi sasaran siswa yang lain yang masih belum memahami materi yang dijelaskan oleh guru kelas. Guru kelas memberikan penjelasan kepada peneliti bahwasannya guru membentuk kelompok saat proses pembelajaran IPA pada kegiatan praktikum memiliki manfaat tersendiri bagi guru dan bagi siswa sendiri, yang mana guru dapat terbantu untuk melakukan suatu penjelasan kembali melalui teman kelompoknya. Sedangkan bagi siswa yang memahami pelajaran yang diberikan oleh guru dapat mengasah kognitifnya seberapa kuat dalam memahami pelajaran yang telah diberikan guru. ${ }^{20}$

Hasil observasi tersebut dapat peneliti simpulkan bahwasannya, implementasi konsep belajar kognitivisme melalui praktikum yang dilakukan oleh guru kelas adalah dengan dipersiapkannya apa yang harus digunakan dalam proses praktikum dengan bantuan siswa dalam memenuhi perangkat yang akan dipraktikkan oleh siswa sendiri. Dan guru selain mempersiapkan materi yang akan diberikan siswa, guru juga mempersiapkan rencana pembelajaran RPP yang telah disusun dan ditulis sedemikian mungkin untuk menunjang keberhasilan dalam proses pembelajaran. Selain yang telah dipersiapkan guru kelas juga melakukan belajar terlebih dahulu materi yang akan disampaikan, dalam proses pebelajaran yang mungkin guru mengalami kesulitan guru mensiasati untuk membuat kelompok dalam belajar, karena siswa akan mengkreasikan dan mengasa pemahaman kognitifnya dengan teman sebayanya dan siswa juga belajar untuk berkomunikasi dengan temannya dengan baik. Pada hasil penelitian pada fakus masalah yang kedua yaitu pelaksanaan konsep belajar kognitivisme dalam mata pelajaran IPA

${ }^{20}$ Observasi, Guru Kelas V, Lumajang, 19 Mei 2018. 
dikelas V SDN Barat 02 Kecamatan Padang Kabupaten Lumajang pada tahun pelajaran 2017-2018. Dari hasil observasi peneliti melihat bahwa dalam proses pembelajaran siswa sudah dapat terlihat peningkatan dalam proses pembelajaran terutama pada mata pelajaran IPA seperti semangat siswa meningkat dalam mengikuti proses belajar mengajar, siswa mudah memahami pelajaran dengan cepat serta siswa dapat mengingat pelajaran lebih lama dari biasanya. Berikut penjelasan dari peningkatan proses pembelajaran siswa dengan mengunakan konsep belajar kognitivisme. Yaitu semangat siswa meningkat dalam mengikuti proses belajar mengajar. Dari hasil observasi peneliti peroleh bahwasannya ketika proses pembelajaran IPA berlangsung dengan menggunakan konsep belajar kognitivisme di SDN Barat 02, siswa terlihat begitu senang, semangat dan aktif dalam pembelajaran. Begitu pula pada siswa yang biasanya mudah melupakan pelajaran dari guru, ia terlihat sangat aktif dalam proses pembelajaran. Karena ia merasa senang bisa belajar sambil melakukan apa yang ia pelajari. Sehingga membuat siswa semangat untuk giat belajar dan mengikuti kegiatan pembelajaran dikelas dan siswa tidak mudah melupakan apa yang telah dialaminya.

Berdasarkan observasi dapat peneliti analisis bahwasanya belajar dengan menggunakan konsep belajar kognitivisme membuat siswa semakin senang dan semangat dalam belajar khususnya pada pelajaran IPA. Karena dalam belajar dengan menggunakan konsep kognitivisme, guru menempatkan siswa sebagai subyek yang aktif dan kreatif dalam pembelajaran, dimana ketika proses pembelajaran berlangsung, siswa didorong untuk berani melakukan kegiatan pelajaran dan berani untuk mengemukakan pendapatnya. Siswa mudah memahami pelajaran dengan cepat serta siswa dapat mengingat pelajaran lebih lama dari biasanya Dari hasil observasi peneliti diperoleh bahwasanya siswa SDN Barat 02 khususnya kelas $\mathrm{V}$, ketika proses pembelajaran IPA berlangsung dengan menggunakan konsep kognitivisme dalam bentuk praktikum mereka 
terlihat sangat antusias dan giat dalam belajar IPA. Siswa pula merasa mudah memahami materi dengan cepat. Walaupun ada beberapa dari siswa yang masih kesulitan dalam melaksanakan praktikum dari guru. Namun, mereka sangat semangat dalam proses pembelajaran. Hal ini dapat dilihat dari proses pembelajaran siswa. Dalam hal ini siswa harus tetap belajar mengingat lebih lama, karena siswa tidak pernah tau kapan pelajaran itu akan diuji kembali oleh guru kelas. Jika siswa tiak bisa menjawab dari ujian yang diberikan guru, maka siswa akan mendapat nilai yang jelek bahkan tidak dapat naik kelas.

Berdasarkan keterangan diatas bahwasanya pembelajaran IPA pada kelas $\mathrm{V}$ dengan menggunakan konsep belajar kogitivisme melalui praktikum, menjadikan siswa lebih mudah memahami materi pelajaran dan mudah mengingat pelajaran. Serta siswa lebih berani dalam mengungkapkan pendapatnya. Hal ini terjadi karena belajar dengan menggunakan praktikum dapat mendorong kognitif siswa bekerja dengan baik dan berani dalam mengungkapakan pendapatnya, sehingga suasana kelas bisa lebih hidup dan tidak monoton, hal inilah yang didapat oleh peneliti pada saat pelaksanaan penelitian di SDN Barat 02 Desa Barat Kecamatan Padang Kabupaten Lumajang.

\section{Penutup}

konsep belajar kognitivisme melalui praktikum dalam mata pelajaran IPA dikelas V SDN Barat 02 yakni guru mempersiapkan materi IPA dengan sebaik mungkin untuk dijadikan bahan praktikum dalam konsep belajar kognitivisme, pada awalnya seorang guru tidak pernah melakukan suatu kegiatan praktikum dalam proses pembelajaran, dengan adanya hal keingginan guru untuk merubah keadaan dalam proses pembelajaran agar siswanya tidak mudah melupakan pelajaran yang telah diberikan dan lupa saat diuji dalam ulangan harian, guru melalukan kegiatan praktik ini pada setiap pertemuan materi yang memang membutuhkan contoh dan praktik sehingga siswa saat melakukan 
kegiatan pembelajaran ini dapat mengingat lebih lama dan tidak mudah melupakan pelajaran yang telah diterimah.

pelaksanaan konsep belajar kognitivisme melalui praktikum dalam mata pelajaran IPA dikelas V SDN Barat 02 dengan persiapan seorang guru dari berbagai hal, dari materi yang akan diberikan kepada siswa, bahan-bahan yang akan digunakan praktik dan rencana pelaksanaan pembelajaran (RPP) yang mana guru mengimplementasikan konsep belajar kognitivisme melalui praktikum dengan beberapa rencana yaitu Guru memberi kesempatan kepada siswa untuk membaca materi sejenak. Lalu Guru memberikan penjelasan tentang materi yang akan dipelajari serta memberi contoh dari materi yang telah dijelaskan. Guru meminta kepada siswa untuk membentuk kelompok. Siswa mendiskusikan apa yang telah dijelaskan oleh guru untuk melakukan praktikum seperti apa yang dicontohkan guru. Siswa menjelaskan dan mempraktikan didepan teman yang lainnya. Guru memberikan ulasan terhadap hasil praktik siswa, selanjutnya bersama-sama siswa dan guru memberi kesimpulan. Dan Guru memberikan motivasi kepada peserta didik.

\section{Daftar Pustaka}

Baharuddin dkk, 2015, Teori Belajar dan Pembelajaran, Yogyakarta, Ar-Ruzz Media.

Dimyati, Wawancara, Barat. 15 april 2018

Hamiyah Nur \& Jauhar Moh, 2014, Strategi Belajar Mengajar di Kelas Jakarta: Prestasi Pustakaraya.

Hartono Rudi, 2013, Ragam Model Mengajar yang Mudah Diterima Murid, Jogjakarta: DIVA Press.

Ima, Wawancara, 20 april 2018

Jauhar Mohammad, 2011 Implementasi PAIKEM, Jakarta: Prestasi Pustakaraya.

Nana Sudjana, 2013, Dasar-Dasar Proses Belajar Mengajar, Bandung: Sinar Baru Algensindo. 
Observasi, Guru kelas V, Barat, 19 Maret 2018.

Observasi. Guru kelas V, Barat, 15 April 2018.

Observasi, Guru Kelas V, Barat, 19 Mei 2018.

Observasi, Guru kelas V, Barat, 21 Mei 2018.

Rine Hartuti, Evi, 2012 Undang-Undang Republik Indonesia Nomor 20 Tahun 2003 Tentang Sistem Pendidikan Nasional, Jogjakarta: Laksana.

Slameto, 2005, Belajar dan Faktor-faktor yang Mempengaruhi Pembelajaran, jakarta: Rineka cipta.

Suwarno dkk, 2010. Materi Lengkap IPA untuk Sekolah Dasar, Jakarta selatan, PT suka buku.

Syah, Muhibbin. 2005. Psikologi Pendidikan dengan Pendekatan Baru, Bandung: Remaja Rosdakarya.

Yogik, Wawancara. Barat: 16 april 2018. 